\title{
Some facts behind graduate's entrepreneurship in Europe
}

\author{
José-Ginés Mora ${ }^{1}$
}

Luis E. Vila ${ }^{2}$

\begin{abstract}
Educational, motivational and economic features are analyzed in a sample of young European graduates to identify the differential elements of entrepreneurship. The results suggest, first, that gender and country of origin are relevant to the decision of becoming an entrepreneur; second, that future entrepreneurs anticipate the higher demands of competence they will face and behave consistently during their studies; and, third, that through entrepreneurship graduates achieve higher earnings and more satisfactory work situations than through the other forms of labor participation.
\end{abstract}

Keywords: education; graduation; entrepreneurship; Europe.

\section{Alguns Fatos por trás do Espírito Empresarial dos Pós-Graduados na Europa}

\begin{abstract}
Resumo: As carcterísticas educacionais, motivacionais e econômicas são analizadas numa amostra de jovens pós-graduados europeus para identificar os elementos diferenciais do espírito empresarial. Os resultados sugerem, em primeiro lugar, que o gênero e o país de origem são relevantes para a decisão de se tornar um empresário; segundo, que os futuros empresários antcipam as demandas mais elevadas de competência que eles enfrentarão e se comportam consistentemente durante os seus estudos; e, terceiro, que através do espírito empresarial os pós-graduados conseguem rendas mais elevadas e situações de trabalho mais satisfatórias do que por meio de outras formas de participação laboral.
\end{abstract}

Palavras-chave: educação; pós-graduação; espírito empresarial; Europa.

JEL: A2, I21.

\footnotetext{
1 Director, Centro de Estudios en Gestion de la Educacion Superior, Universidad Politecnica de Valencia. E-mail: josegines@upv.es.

2 Profesor, Departamento de Economia Aplicada, Universidad de Valencia. E-mail: Luis.Vila@uv.es.
} 


\section{Introduction}

Entrepreneural activities appear as a key driving force of both economic and social development in an increasingly global environment where the employee culture is becoming less dominant, and the entrepreneurial culture must be fostered. From individuals' viewpoint, life-long employment in one company is no longer the norm, and may be even less so in the future, so one way to meet this challenge is to consider starting up an own business. The European Commission encourages of the increasing importance of entrepreneurs in wealth creation in the new economy, the factors that may influence entrepreneurial behavior are poorly understood, and there are very few studies on entrepreneurial activities of higher education graduates (Folster 2000).

The literature defines entrepreneurs as the persons who create a new company, contribute with new products to the market, or develop new processes of production (Stiglitz \& Driffill, 2000; Nijkamp, 2003). A relevant body of research on entrepreneurial activities reveals that there is a consistent interest to identify what are the factors that lead an individual to become entrepreneur. The evidence revealed that these factors were basically the same across different studies (Delmar and Davidsson, 2000). Age, gender, professional background, work experience, and educational and psychological profiles have been frequently analysed. In general, the results indicate that being a man between 25 to 40 years old, with self-employed parents, a higher education degree, need for achievement, risk-taking propensity, and preference for innovation are the factors favouring the decision of undertaken entrepreneurial activities (Storey 1994; Reynolds 1997; Stewart et al. 1998; Delmar \& Davidsson 2000). Blanchflower (2000) pointed out that the entrepreneural activity and its determinants are quite different from one country to another, so cross-cultural studies have tried to identify latent or nascent entrepreneurs (Blanchflower et al. 2001; Arenius \& Minniti 2005) and the motivations to become self-employed (Colombo \& Desmastro 2001; Smallbone \& Welter 2001).

In the analyses of the elements influencing entrepreneurship, a key difficulty is to empirically differentiate true entrepreneurs from the rest of population because too often surveys classify true entrepreneurs, independent professionals and other self-employed within the same category (Mueller \& Thomas, 2000). Self-employment is a label regularly used to include a variety of forms of participation in economic activity: own-account workers, contractors, employers, members of co-operatives, independent professionals and even unpaid family workers are usually classified as self-employed workers. Nonetheless, self-employment may be regarded either as a survival strategy for those who could not find any other mean of earning an income or as a desire to be one's own boss, evidencing a hint for the entrepreneurial spirit (OECD 2006). Beugelsdijk \& Noorderhaven (2005) consider the notion of self-employment somehow broader than that of entrepreneur. They use the 
examples of the agricultural sector and the small family firms that pass from parents to children. In labour market surveys, individuals in such cases are registered as self-employed but it is not clear if they are genuine entrepreneurs. Something similar applies to professionals such as medical doctors, architects, lawyers, etc.; while some of they may have started a new bussines company, others work for firms or companies owned and ruled by third persons.

However, the idea of becoming entrepreneur may be really attractive for many young higher education graduates because it is often seen as a desirable form to participate in the economic activity without loosing personal independence. In order to explain this increasing interest a number of papers analysed the change in the values of students regarding the traditional firms and companies, as well as their attitudes towards entrepreneurship and the idea of initiating a business. Lüthje \& Franke (2003) reported that the most extended values among graduates facing the new economy's labour market are consistent with those generally required in entrepreneural activities: independence, challenge and self-realisation.

Within this framework, this paper explores several educational features of higher education graduates likely to influence their decision of becoming entrepreneurs, including the accuracy of the match between education and work, as well as the labor market status associated to the entrepreneural activity. Using a large sample of young higher education graduates from EU countries, the analysis focuses on educational, motivational and economic differences among three categories of graduates: entrepreneurs, non-entrepreneur selfemployed, and employees. The structure of this paper is as follows: section 2 presents the data set and establishes a criterion for identifying entrepreneur graduates, section 3 shows and discusses the main results, and section 4 concludes with a summary and some implications derived from the analysis for diverse social agents.

\section{Data set}

In this paper we analyse data from CHEERS (Careers after Higher Education - A European Research Survey), a major representative survey comparing the situation of young European graduates from higher education institutions (Schomburg \& Teichler 2006). Graduates from 1995 were surveyed in 1999, four years after their graduation. Almost 40,000 graduates from 9 European Union countries (Italy, Spain, France, Austria, Germany, the Netherlands, United Kingdom, Finland, Sweden), Norway, the Czech Republic Japan provided information through a written questionnaire. The respondents provided information on their socio-biographic background, study paths, transition from higher education to employment, early career, links between study and employment, self-assessment of their life goals and jobs prospects as well 
as their retrospective view of higher education. The relevant question to our definition of entrepreneur was not asked in the questionnaires of several countries which has been excluded in our analysis.

For the purpose of this paper we select only those graduates that declared to be "employed" or "self-employed" in the answer to the question "Please state the kind of your current employer/institution". The subgroup of employees is further divided into graduates working for public, private non-profit, and for-profit private organisations. To identify entrepreneurs we select, within the subgroup of self-employed, those graduates that marked the item "I established a new firm/office" in the question "If you are self-employed: Which of the following characteristics are applicable to you?" The valid sample contains 19,746 records classified as follows: $4 \%$ entrepreneurs according to our definition, $5 \%$ otherwise self-employed, and $91 \%$ employees (34\% public employees, $8 \%$ non-profit organisation employees, $49 \%$ working for a private employer).

Surveyed graduates obtained their degrees 4 years before the interview. They were asked both about their current situation and their experience as higher education students. Selecting individuals currently working as entrepreneurs and not those who were trying to create a company but they have not yet, or those who did it but went out of business, give us the opportunity to work in real time. Another relevant aspect is the sample size from different countries which it permits to aim for cross country comparisons, as well as to analyse the relations between the different groups participating in the labour market. Our data allow us to examine and extend the existing results on entrepreneur's with new variables like competences. Results in the following section differentiate entrepreneurs from self-employed and by extension from the rest of employees in order to analyse the elements leading to a given choice of participation in the labour market, as well as the consequences emerging from the work market status associated to the chosen form of participation.

Table 1 shows the distribution by countries of the surveyed young European graduates. It is necessary to make a previous consideration: the number of self-employed is not necessarily consistent by countries, in some cases this option might be related more directly with the kind of labour statute of certain labour professions (lawyers, physicians, etc.) than with the personal preferences of the individuals.

Table 1 shows that Italians graduates have the highest rate of entrepreneurs and self-employed, at the same time Italy is the country with less employees working for non-profit organisations. Spanish graduates are characterised by the highest percentage of young graduates employed by private companies. France and UK share the lowest rate of entrepreneurs among their young graduates. In The Netherlands the percentage of graduates working for non-profit organisations are really high probably due to a specific definition of non-profit organisation in this country. Finally in Finland the high per- 
centage of graduates in the public sector (in contrast to the private sector) is remarkable.

TABLE 1- TYPE OF EMPLOYMENT BY COUNTRY

\begin{tabular}{lccccccccc}
\hline & II & ES & FR & AT & DE & NL & UK & FI & Total \\
\hline Entrepreneurs (n) & 189 & 92 & 18 & 109 & 124 & 95 & 40 & 75 & 742 \\
\% on the country sample & 8 & 4 & 1 & 5 & 4 & 4 & 1 & 3 & 4 \\
Self-employed (n) & 275 & 103 & 29 & 110 & 212 & 85 & 91 & 46 & 951 \\
\% on the country sample & 11 & 5 & 1 & 6 & 7 & 3 & 3 & 2 & 5 \\
\hline Employes (n) & 1,947 & 1,969 & 1,969 & 1,765 & 2,752 & 2,489 & 2,820 & 2,342 & 18,053 \\
\% on the country sample & 81 & 91 & 98 & 89 & 89 & 93 & 96 & 95 & 91 \\
Public employees (n) & 564 & 645 & 708 & 652 & 1,172 & 773 & 1,086 & 1,341 & 6,941 \\
\% on the country sample & 23 & 30 & 35 & 33 & 38 & 29 & 37 & 54 & 34 \\
Non-profit organisation $(n)$ & 84 & 87 & 127 & 209 & 150 & 553 & 181 & 134 & 1,525 \\
\% on the country sample & 3 & 4 & 6 & 11 & 5 & 21 & 6 & 5 & 8 \\
Private employees $(n)$ & 1,299 & 1,237 & 1,134 & 905 & 1,430 & 1,163 & 1,553 & 867 & 9,588 \\
\% on the country sample & 54 & 57 & 56 & 46 & 46 & 44 & 53 & 35 & 49 \\
\hline \hline
\end{tabular}

Source: OECD (2006).

Table 2 shows the percentages by gender of each form of labour market participation included in our sample. Among the entrepreneurs surveyed, 66\% are male, almost double than the percentage of female, $34 \%$. This pattern is less significant in the case of other self-employed ( $54 \%$ male $46 \%$ female) and disappears with employees. Within the employees group there are more women working in the public sector and for non-profit organisation than in the private sector. Nevertheless, men are predominant in the private sector. This differentiation by gender confirms that entrepreneurship activities are more related to males, as literature says. On the other hand, the greater proportion of women within employees that work for public employers and non-profit organizations is remarkable. The explanation of these differences deserves further and specific research.

TABLE 2. TYPE OF EMPLOYMENT BY GENDER

\begin{tabular}{lrcccrr}
\hline & \multicolumn{2}{c}{ Male } & \multicolumn{3}{c}{ Female } & \multicolumn{2}{c}{ Total } \\
\cline { 2 - 7 } & \multicolumn{1}{c}{$\mathbf{n}$} & $\%$ & $\mathbf{n}$ & $\%$ & \multicolumn{1}{c}{$\mathbf{n}$} \\
\hline Entrepreneurs & 491 & 66 & 251 & 34 & 742 \\
Self-employed & 511 & 54 & 434 & 46 & 945 \\
Employees & 9,027 & 50 & 8,961 & 50 & 17,988 \\
Public employees & 2,865 & 41 & 4,050 & 59 & 6,915 \\
Non-profit organisation & 490 & 32 & 1,024 & 68 & 1,514 \\
Private employees & 5,673 & 59 & 3,888 & 41 & 9,561 \\
\hline Total & 10,030 & 51 & 9,647 & 49 & 19,677 \\
\hline
\end{tabular}

Source: OECD (2006). 


\section{Results}

Results describe how graduates display rather different profiles regarding three aspects: a) educational characteristics, (previous to higher education, during higher education studies and after finishing first higher education degrees); b) education-job match (to what extent individual competences and motivations match the actual requirements of jobs); and c) job characteristics (income, satisfaction, etc).

2.1 Educational characteristics

In this section we will review some educational characteristics of young graduates: rating of entrance grades, years of previous schooling, years actually studied, study activities and extra-curricular activities and further education/ training.

2.1.1 Rating of entrance grades into higher education and years of previous schooling

Table 3 shows that from the three forms of labour market participation analysed, self-employed graduates had on average the lowest entrance grades into higher education. In addition self-employed spend more time on average to finish schooling (primary plus secondary). In contrast, the highest marks go to the group of employees and they needed less time to get into higher education. The case of entrepreneurs is remarkable: they spend more time to finish their studies than employees but they have similar marks.

Analysing in detail the group of employees those who work for a public employer are characterised for obtaining the highest mark on average, they are the quickest finishing their studies of primary and secondary education. Private employees and entrepreneurs share similar characteristics in the marks and in the years of schooling altogether. These data suggest a possible pattern emerging from the pre-higher education behaviour that can be expressed in a very simplistic way as follow. "Good" students (higher marks and lower duration) will become public employees. Nevertheless, entrepreneurs (good marks but longer duration) have a certain tendency towards "dispersion" (more time during previous studies). 
TABLE 3. TYPE OF EMPLOYMENT BY ENTRANCE GRADES TO HIGHER EDUCATION AND PREVIOUS YEARS OF SCHOOLING - MARKS RUNS FROM 1 (LOW) TO 3 (HIGH)

\begin{tabular}{lcccc}
\hline & \multicolumn{2}{c}{ Rating of grades } & \multicolumn{2}{c}{ Ye ars of schooling } \\
\cline { 2 - 5 } & Mean & SD & Mean & S D \\
\hline Entrepreneurs & 2.06 & 0.71 & 12.8 & 1.04 \\
Self-employed & 2.02 & 0.70 & 12.8 & 1.02 \\
Employees & 2.07 & 0.71 & 12.7 & 1.06 \\
Public employe es & 2.12 & 0.70 & 12.7 & 1.06 \\
Non-profit orga nisation & 1.98 & 0.70 & 12.7 & 1.20 \\
Private employees & 2.05 & 0.72 & 12.7 & 1.04 \\
\hline
\end{tabular}

Source: OECD (2006)

2.1.2 Years actually spend in higher education

Table 4 presents the scores of recent graduates related to the following question "How long did you study in higher education for earning the degree you were awarded and what period is normally/by law required?” Entrepreneurs and self-employed chose longer studies and need more years to finish them with highest percentages of over-duration in their studies (37\%-38\% more than required). Employees, particularly graduates working in the public sector, spend on average less time to finish their studies (taking into account the rate between years actually studied and years by law required). Again results suggest different study patterns between entrepreneurs and employees, especially public sector employees. Entrepreneurs chose probably more challenges studies, but they are not especially fast in finishing their studies.

TABLE 4. TYPE OF EMPLOYMENT BY YEARS AND DURATION OF STUDIES

\begin{tabular}{|c|c|c|c|c|c|}
\hline & \multicolumn{2}{|c|}{$\begin{array}{c}\text { Years actually } \\
\text { studied }\end{array}$} & \multicolumn{2}{|c|}{$\begin{array}{l}\text { Years normally/by } \\
\text { law required }\end{array}$} & \multirow{2}{*}{$\begin{array}{c}\text { Over duration } \\
\text { of st udies } \\
\text { Percentag }\end{array}$} \\
\hline & Mean & SD & Mean & SD & \\
\hline Entrepreneurs & 5.96 & 2.29 & 436 & 0.88 & 37 \\
\hline Self-employed & 5.88 & 2.44 & 4.25 & 0.88 & 38 \\
\hline Employees & 4.96 & 2.05 & 4.03 & 1.00 & 23 \\
\hline Public employees & 4.90 & 2.20 & 4.06 & 1.08 & 21 \\
\hline Non-profit organisation & 4.79 & 2.05 & 3.94 & 1.01 & 22 \\
\hline Private employees & 5.03 & 1.93 & 4.02 & 0.93 & 25 \\
\hline
\end{tabular}

Source: OECD (2006).

2.1.3 Study activities and extra-curricular activities

We describe in table 5 the number of hours in different study activities during a regular period of lectures. We observed in table 4 that entrepreneurs and self-employed need more time to finish their studies, one possible explanation is the fact that they spend part of their time in other activities. Analysing these activities in table 5, we observe that entrepreneurs differ from employees in 
the pattern of activities. Entrepreneurs spend more time working in order to acquire professional experience, more time in extra curricular activities, more time in other study activities and less time attending lectures. Public employees and non-profit organisation employees do not show this kind of curiosity for extra-curricular activities or other study activities. This information suggests that the study period offered the opportunity to acquire supplementary skills. Again, a different pattern emerges: future entrepreneurs spend more time in "irregular" activities that the rest of students and less time in passive activities such as attending lectures.

TABLE 5. TYPE OF EMPLOYMENT BY HOURS PER WEEK IN DIFFERENT STUDY ACTIVITIES

\begin{tabular}{lcccccccc}
\hline & $\begin{array}{c}\text { Major subjects: } \\
\text { at tending } \\
\text { lectures }\end{array}$ & $\begin{array}{c}\text { Major } \\
\text { subjects: other } \\
\text { study activities }\end{array}$ & $\begin{array}{c}\text { Extra- } \\
\text { curricular } \\
\text { activities }\end{array}$ & Employment \\
\hline Entrepreneurs & Mean & SD & Mean & SD & Mean & SD & Mean & SD \\
Self-employed & 16.7 & 10.7 & 16.2 & 11.7 & 5.2 & 6.2 & 8.0 & 11.7 \\
Employees & 16.1 & 10.0 & 16.9 & 12.2 & 5.1 & 6.1 & 5.8 & 9.3 \\
Public employees & 17.6 & 10.3 & 14.8 & 10.8 & 4.9 & 5.8 & 5.9 & 9.9 \\
Non-profit organisation & 16.6 & 10.2 & 14.4 & 10.9 & 4.5 & 5.7 & 6.5 & 10.8 \\
Private employees & 15.3 & 9.7 & 13.3 & 9.7 & 4.2 & 5.3 & 7.5 & 10.7 \\
\hline
\end{tabular}

Source: OECD (2006).

\subsubsection{Further education and training}

Table 6 provides information about the percentages of graduates that undertake further education and training since graduation. Almost half of the self-employed graduates (48\%) had undertaken further education. The percentage in the group of entrepreneurs (44\%) is quite high as well. The group of employees shows low percentages, particularly those graduates working for private companies with the lowest percentage (28\%). Looking at the percentages analysed above, it seems plausible to think that entrepreneurs and self-employed are facing the requirements of the new knowledge society given more importance to continuing learning.

TABLE 6. PERCENTAGE OF GRADUATES TAKING FURTHER EDUCATION OR TRAINING, BY TYPE OF EMPLOYMENT

\begin{tabular}{lc|}
\hline & Total \\
Entrepreneurs & 44 \\
Self-employed & 48 \\
Employees & 34 \\
Public employees & 40 \\
Non-profit orga nisation & 33 \\
Private employees & 28 \\
\hline
\end{tabular}

Source: OECD (2006). 
2.2 Accuracy of the education-job match

In this section match between acquired and required competences and motivation to work and related characteristics of the current working situation will be taken into account.

\subsubsection{Competences at time of graduation (acquired competences) and required in the current work}

Table 7 shows the scores of the acquired and required competences among the graduates surveyed with the averages of the questions: "State the extent to which you had the following competences at time of graduation" and "To what extent the following competences are required in your current work" (in a 5 point scale, from 1 "not at all" to 5 "to a very high extent").

In regard to acquired competences, the three groups analysed evaluate the competence "learning abilities" with the highest score and "negotiating" with the lowest. Main differences between entrepreneurs and self-employed are observed in the following competences: leadership, working under pressure, analytical competences, working in a team, taking responsibilities and work independently. In these competences the scores of entrepreneurs are much higher than the scores for self-employed. Comparing entrepreneurs with employees, the most significant differences (higher average for entrepreneurs) can be appreciated in leadership and taking responsibilities. On the other hand, the group of employees shows higher scores on average than entrepreneurs in the following competences: time management (especially public employees), computer skills (especially private employees) and work in a team (especially non-profit organisation employees). Self-employed evaluate more positively than entrepreneurs the competence time management. Leadership and taking responsibilities (decisions) are two competences acquired by entrepreneurs at time of graduation that allow us to differentiate them from the rest of graduates surveyed. In the same sense but related with the lowest acquired competence by entrepreneurs we remark time management. 
MORA, J. \& VILA, L. Some facts behind graduate's...

TABLE 7. ASSESSMENT OF COMPETENCES AT TIME OF GRADUATION (ACQUIRED COMPETENCES), REQUIRED COMPETENCES AT WORK AND DEFICITS BY TYPE OF EMPLOYMENT

\begin{tabular}{|c|c|c|c|c|c|c|c|c|}
\hline \multirow[t]{2}{*}{ Motives (M) } & \multicolumn{2}{|c|}{ Entrepreneurs } & \multicolumn{2}{|c|}{ Self-employed } & \multicolumn{2}{|c|}{ Emplovees } & \multicolumn{2}{|c|}{ Public Employes } \\
\hline & Mean & SD & Mean & SD & Mean & SD & Mean & SD \\
\hline Independent disposition of work & 446 & 0.76 & 4.29 & 0.82 & 4.01 & 0.89 & 4.05 & 0.91 \\
\hline Opportunity of pursing avn ideas & 440 & 0.74 & 4.24 & 0.83 & 4.13 & 0.8 & 4.14 & 0.82 \\
\hline Challenging tasks & 4.21 & 0.83 & 405 & 0.89 & 4.06 & 0.86 & 4.01 & 0.90 \\
\hline Enough time for leisure adtivities & 3.84 & 1.03 & 3.93 & 1.01 & 4.05 & 0.92 & 4.09 & 0.92 \\
\hline High income & 377 & 1.00 & 3.65 & 0.96 & 3.70 & 0.92 & 3.58 & 0.96 \\
\hline Co-crdinating and managerial tasks & 3.66 & 1.09 & 341 & 1.08 & 345 & 1.04 & $3 \cdot 27$ & 1.08 \\
\hline Job security & 355 & 1.24 & 3.77 & 1.13 & 4.11 & 0.97 & 4.26 & 0.91 \\
\hline Possibility of working in a team & 3.54 & 1.07 & 347 & 1.09 & 3.76 & 0.95 & 3.74 & 0.98 \\
\hline Social recognitionand status & 3.29 & 1.11 & 3,31 & 1.09 & 3.31 & 1.05 & 3,34 & 1.05 \\
\hline \multirow[t]{2}{*}{ Current Situation (CS) } & \multicolumn{2}{|c|}{ Entrepreneurs } & \multicolumn{2}{|c|}{ Self-employed } & \multicolumn{2}{|c|}{ Employees } & \multicolumn{2}{|c|}{ Public Emplayees } \\
\hline & Mean & SD & Mean & SD & Mean & SD & Mean & SD \\
\hline Independent disposition of work & 444 & 0.83 & 423 & 0.95 & 3.67 & 1.09 & 3.71 & 1.11 \\
\hline Opportunity of pursuing own ideas & 4.13 & 0.94 & 386 & 1.05 & 3.54 & 1.10 & 3.57 & 1.14 \\
\hline Challenging tasks & 4.10 & 0.97 & 3.81 & 1.09 & 3.73 & 1.10 & 3.76 & 1.10 \\
\hline Co-ordinating and managerial tasks & 3.72 & 1.20 & 3.24 & 1.30 & 3.11 & 1.20 & 2.94 & 1.19 \\
\hline Social recogri tion and status & 344 & 1.01 & 334 & 1.09 & 3.23 & 1.05 & 3.22 & 1.07 \\
\hline Possibility of working in a team & 340 & 1.25 & 3.21 & 1.23 & 3.75 & 1.06 & 3.74 & 1.06 \\
\hline High income & 3.11 & 1.26 & 283 & 1.23 & 2.95 & 1.11 & 2.77 & 1.10 \\
\hline Job security & 308 & 1.37 & 306 & 140 & 3.70 & 1.26 & 3.72 & 1.38 \\
\hline Enough time for leisure acti vi ties & 307 & 1.26 & 3.13 & 1.22 & 3.22 & 1.20 & $342^{2}$ & 1.18 \\
\hline Differences: M-CS & \multicolumn{4}{|c|}{ Entrepreneurs Self-employed } & \multicolumn{2}{|c|}{ Employees } & \multicolumn{2}{|c|}{ Public Empioyees } \\
\hline Independent disposition of work & \multirow{2}{*}{\multicolumn{2}{|c|}{$\begin{array}{l}0.02 \\
0.27\end{array}$}} & \multicolumn{2}{|c|}{0.06} & \multicolumn{2}{|c|}{0.34} & \multicolumn{2}{|c|}{0.34} \\
\hline Opportunity of pursuing own ideas & & & \multirow{2}{*}{\multicolumn{2}{|c|}{$\begin{array}{l}0.38 \\
0.24\end{array}$}} & \multicolumn{2}{|c|}{0.59} & \multicolumn{2}{|c|}{ o. 57} \\
\hline $\begin{array}{l}\text { Challenging tasks } \\
\text { Enough time for leisure acti vi ties }\end{array}$ & 0.77 & $\begin{array}{l}0.27 \\
0.11\end{array}$ & & 0.80 & \multicolumn{2}{|c|}{$\begin{array}{l}0.33 \\
0.83\end{array}$} & \multicolumn{2}{|c|}{$\begin{array}{l}0.25 \\
0.67\end{array}$} \\
\hline $\begin{array}{l}\text { Enough time for lessure activ ties } \\
\text { High income }\end{array}$ & \multicolumn{2}{|c|}{0.66} & \multicolumn{2}{|c|}{0.82} & \multicolumn{2}{|c|}{0.75} & \multicolumn{2}{|c|}{ o. 81} \\
\hline Co-ordinating and managerial tasks & & & & & 0.3 & & & \\
\hline Job security & & 47 & & & 0.4 & & & \\
\hline Possibility of working in a team & & 14 & & & 0.0 & & & \\
\hline$\underline{\text { Social recogri tion and status }}$ & & 15 & & & 0.0 & & & \\
\hline
\end{tabular}

Source: OECD (2006). 
In regard to required competences, table 7 shows that the entrepreneur's group (as well as self-employed) has higher scores on average in the following required competences: working independently and taking responsibilities (decision). Comparing with self-employed the highest differences can be appreciated in the following competences: planning co-ordinating and organising, analytical competences, leadership and negotiating. The competence with more differences in the scores of entrepreneurs and employees is negotiating (public employees 3.51, entrepreneurs 4.13). Other competences with high distances between employees and entrepreneurs are: working independently, taking responsibilities (decisions), critical thinking and leadership. Working in a team is much higher perceived as a required competence for employees, for example, graduates working for non-profit organisations score on average 4.31 and entrepreneurs only 3.89. If we analysed tables 10 and 11 altogether, it is interesting to notice that the differences between entrepreneurs, self-employed and employees are higher regarding required competences than acquired ones. In both tables the highest scores are for the group of entrepreneurs followed by the group of self-employed group and finally the group of employees. The entrepreneur's self-assessment about required and acquired competences seems to draw a constant pattern: to become entrepreneur it is important to know that entrepreneurs are more demanded comparing them with the rest of graduates of our sample. It means that those graduates thinking about the possibility to become entrepreneurs need to bear in mind the importance of developing a high level of competences to feel well prepared to transfer their competences into the practical area of application.

2.1.2 Motivation to work and related characteristics of the current working situation

Table 8 is the merge of three tables with the assessment of recent graduates to the following two questions: "how important are the following characteristics of an occupation for you personally (first table: motivation to work) and to what extent do they apply to your current professional situation (second table: characteristics of the professional situation)". The third table shows the differences of table 1 and 2 to explore the match of graduates' expectations. These tables allow us to appreciate the high importance the entrepreneurs give to the item "Largely independent disposition of work" followed by item "Opportunity of pursuing own ideas" and then "Challenging tasks". The main difference from first and second table is that in the current professional situation entrepreneurs give more importance to "Co-ordinating and management tasks". Entrepreneurs and self-employed differ largely is the higher importance the second group gives to "job security". The bigger differences are between entrepreneurs and employees, for example, public Employees state that "job security" is the most important motivation to work, the difference between entrepreneurs (3.55) and public employees (4.26) is remarkable. Another 
MORA, J. \& VILA, L. Some facts behind graduate's...

aspect to stress is the importance employees give to the "possibility of working in a team", particularly employees working for a non-profit organisation. The latter group is also highly motivated to work if they have "enough time for leisure activities". Comparing private employees with the rest of graduates, they are relatively more motivated if they receive "high income".

As expectable, the characteristics of work situation do not fully match the motives of the graduates surveyed. Entrepreneurs, self-employed and employees are generally disappointed about "enough time for leisure activities" and "high income". On the other hand, the motives of entrepreneurs are fully met on average, as far as "social status and recognition" as well as "co-ordinating and management tasks" are concerned. Self-employed share "social status and recognition" with the entrepreneurs group and, finally the employees expectations almost met the "possibility of working in a team". 
MORA, J. \& VILA, L. Some facts behind graduate's...

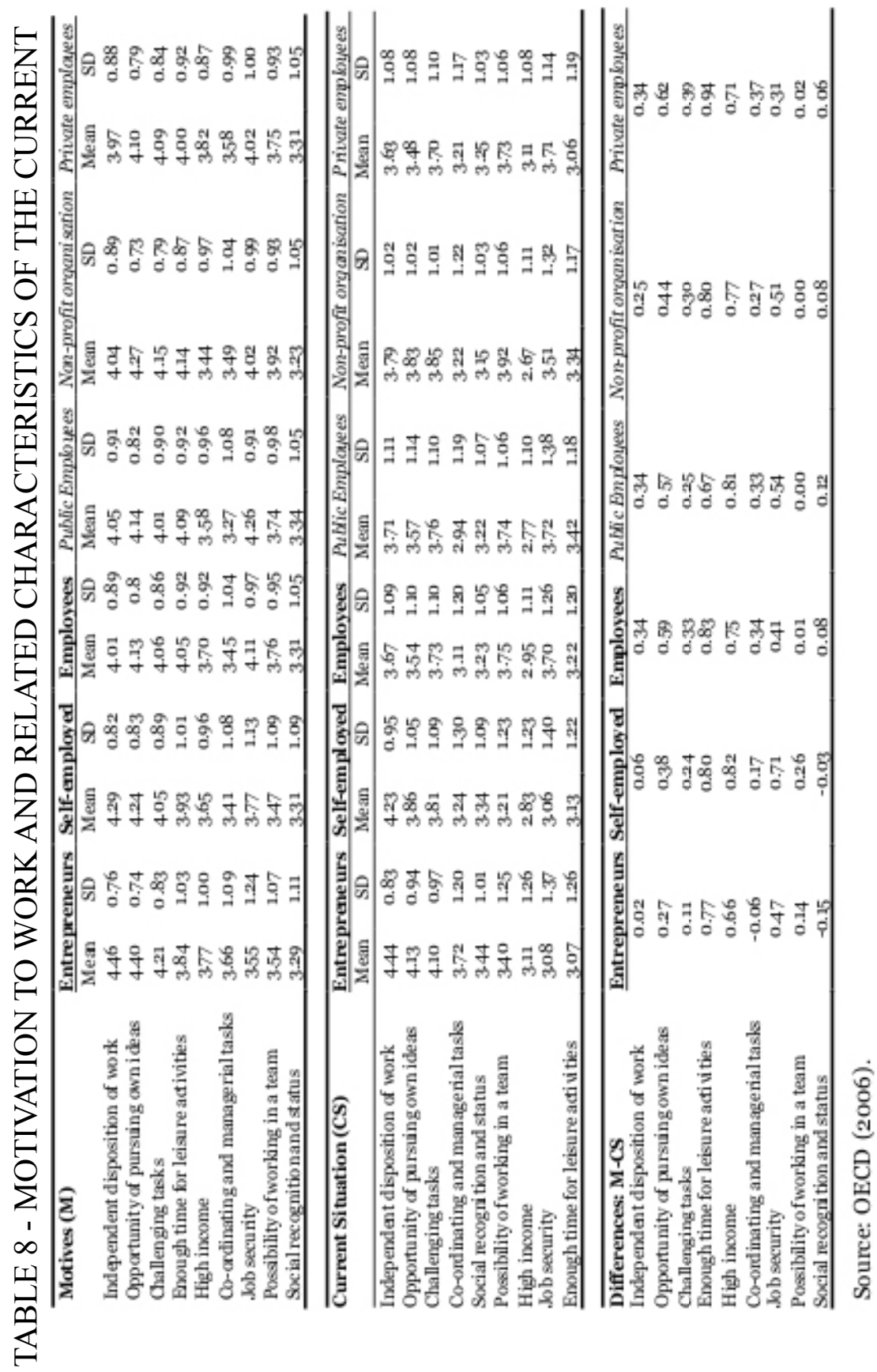

Revista de Economia, v. 35, n. 3 (ano 33), p. 147-164, set./dez. 2009. Editora UFPR 
2.3 Job characteristics

Finally, we present in this section some job characteristics of different types of graduates.

\subsubsection{Income}

Table 9 shows the annual gross income of recent graduates from their current major job (excluding overtime and extra payments). We observe that the highest earnings correspond to the group of entrepreneurs comparing them with self-employed and the average of employees. The differences among graduates surveyed are large. Analysing in detail the groups of employees, the highest earnings are for graduates working for a private employer (exceeded even the income of entrepreneurs). It is somehow surprising that self-employed earn the lowest income; it should be noticed that that we are not considering extra payments or incomes from other jobs, otherwise the self-employed earnings will probably be higher.

TABLE 9. ANNUAL GROSS INCOME BY TYPE OF EMPLOYMENT

\begin{tabular}{lcc}
\hline & \multicolumn{2}{c}{ Income - major activity C } \\
\cline { 2 - 3 } & Mean & SD \\
\hline Entrepreneurs & 26,774 & 22,434 \\
Self-employed & 23,122 & 19,408 \\
Employees & 25,353 & 15,597 \\
Public employees & 23,101 & 12,984 \\
Non-profit organisation & 21,622 & 12,447 \\
Private employees & 27,564 & 17329 \\
\hline
\end{tabular}

Source: OECD (2006).

2.3.2 Working hours per week

The results of table 10 indicate that entrepreneurs, with a total of 47 working hours per week, show the highest level of working hours on average. The second highest score is for private employees with 45 working hours per week. Self-employed and entrepreneurs show high differences: self-employed work 5 hours less than entrepreneurs, which suggests that the dedication of more time is necessary for the activity of entrepreneurs. 
TABLE 10 - TOTAL WORKING HOURS PER WEEK BY TYPE OF EMPLOYMENT

\begin{tabular}{lcc}
\hline & \multicolumn{2}{c}{ Working hours per week } \\
\cline { 2 - 3 } & Mean & SD \\
\hline Entrepreneurs & 47 & 14 \\
Self-employed & 42 & 16 \\
Employees & 43 & 12 \\
Publice mployees & 42 & 13 \\
Non-profit organisation & 40 & 12 \\
Private employees & 45 & 11 \\
\hline
\end{tabular}

Source: OECD (2006)

2.3.3 Job satisfaction

Table 11 illustrates the general satisfaction on average (in a 5-point scale, from 1 "very dissatisfied" to 5 "very satisfied") with current work among graduates surveyed. Entrepreneurs are the more satisfied within the sample, while self-employed are the more unsatisfied group. This fact supports the notion of differentiating both groups. Public sector employees and non-profit organisation employees are more satisfied than private sector ones. The low level of satisfaction for private employees is remarkable because this is the group with the highest income. One possible explanation can be found in the fact that people holding a permanent contract are more satisfied with their jobs, and private employees perceive some kind of labour instability affecting their general satisfaction. Entrepreneurs are the more satisfied group with their work among the graduates of our sample, even when they work longer hours and earn less than their colleagues from the private sector.

TABLE 11. GENERAL SATISFACTION ON AVERAGE WITH CURRENT WORK BY TYPE OF EMPLOYMENT

\begin{tabular}{lcc}
\hline & \multicolumn{2}{c}{ General Satisfaction with current work } \\
\cline { 2 - 3 } & Mean & SD \\
\hline Entrepreneurs & 3.9 & 0.9 \\
Self-employed & $3 \cdot 5$ & 1.0 \\
Employees & 3.7 & 1.0 \\
Public employees & 3.8 & 1.0 \\
Non-profit organisation & 3.7 & 1.0 \\
Private employees & 3.6 & 1.0 \\
\hline
\end{tabular}

Source: OECD (2006). 


\section{Conclusions}

The analysis of educational and economic differences among graduate entrepreneurs, other self-employed, and employees reveals that they display rather different profiles regarding both the educational elements leading to their occupational decisions after graduation and the economic status emerging from these decisions.

First, both gender and country of residence appear as relevant determinants among the elements influencing the decision of becoming entrepreneur. The proportions of graduates who started their own firms are much higher for men than for woman, and do vary widely by country, with Italy on top and France at the low end.

Second, the retrospective view of entrepreneur graduates about their educational experience clearly characterise them as a separate group with specific features. Compared to the rest of graduates, entrepreneurs obtained in average higher grades in secondary education, suggesting a higher level of ability, but they took longer to obtain their higher education degrees, possibly because they performed additional (entrepreneurial?) activities during their study period. As students, future entrepreneur graduates preferred to spend their time gaining practical experience than attending lectures. Remarkably, those graduates who started up their own business undertook further education and training in higher proportions that the rest of graduates, perhaps anticipating that they were going to need additional knowledge and competencies in their future entrepreneurial activities. All groups of surveyed graduates agreed in negatively evaluate the practical experience provided by the educational institutions, but entrepreneur graduates appeared especially concerned about the difficulties their institutions faced to provide them with practical experience and with the necessary conditions to facilitate their access to the world of work. Entrepreneur graduates also showed a characteristic profile regarding the combination of competences they possessed at the time of graduation: compared to other graduates, entrepreneurs scored relatively higher in the competences of leadership and taking responsibilities, and relatively lower in time management.

Third, our analysis reveals that those graduates who became entrepreneurs achieved in general work stata clearly different from those achieved by the rest of graduates. Major differences were found in terms of the competences required in their occupation: entrepreneur graduates undertook in general more demanding activities and tasks and, consequently, a selective set of competences appeared as key factors for entrepreneurship: negotiating, working independently, taking responsibilities and decisions, critical thinking and leadership. Besides, entrepreneurs earned in average higher incomes and were more satisfied with their jobs, although they worked longer hours than the other graduates did. They also showed different motivation to work: 
enjoying an independent disposition, which provided them with the opportunity of following their own ideas, and the challenge represented by the risks taken were the key motivational elements for graduates who became entrepreneurs.

The decision of becoming an entrepreneur and its effects may be capital for diverse social agents. Students and graduates form their expectations and make their educational and occupational decisions according to their preferences under personal, social, and financial constrains, and they know their future economic performance would depend upon this decision. Academics and managers organise the provision of study places and decide over the modes of teaching and learning, shaping the competencies graduates would bring into the production system. Moreover, entrepreneurial attitudes in people may be promoted or discouraged during their educational experience. Finally, policy makers elaborate and implement the mechanisms aimed at increasing productivity and improve equity, which ultimately define the framework under which modern societies shall operate. Education policy, as well as taxation and credit policies, may help to generate favourable atmospheres for entrepreneurship in the EU. The implications of our analysis suggests, in spite of its evident limitations, that the forces behind the decision of starting a business and the consequences this decision generates for the individuals who take it are complex and deserve further efforts by researchers from diverse backgrounds to be better understood.

\section{References}

ARENIUS, P. \& MINNITI, M. (2005). "Perceptual Variables and Nascent Entrepreneurship”. Small Business Economics, 24:233-247.

BEUGELSDIJK, S. \& NOORDERHAVEN, N. (2005). "Personality Characteristics of Self-employed: an Empirical Study." Small Business Economics, 24:159-167.

BLANCHFLOWER, D. (2000). "Self-employment in OECD Countries." Labour Economics, 7:471-505.

BLANCHFLOWER, D. \& OSWALD, A.; STUTZER, A. (2001). "Latent Entrepreneurship Across Nations.” European Economic Review, 45:680-691.

COLOMBO, M. \& DESMASTRO, M. (2001). “Technology Based Entrepreneurs: Does Internet Make a Difference?.” Small Business Economics, 16:177-190.

DELMAR, F. \& DAVIDSSON, P. (2000). "Where Do They Come From? Prevalence and Characteristics of Nascent Entrepreneurs." Entrepreneurship \& Regional Development, 12:1-23.

EUROPEAN COMMISSION (2000). Toward Enterprise Europe: Work programme for enterprise policy 2000-2005: Commission staff working paper. Document No. SEC (2000) 771. Brussels.

FÖLSTER, S. (2000). “Do Entrepreneurs Create Jobs?” Small Business Economics, 
MORA, J. \& VILA, L. Some facts behind graduate's...

14:137-148.

LÜTHJE, C. \& FRANKE, N. (2003). "The 'Making' of an Entrepreneur: Testing a Model of Entrepreneurial Intent among Engineering Students at MIT.” R\&D Management, 135:147.

MUELLER, S. \& THOMAS, A. (2000). Culture and Entrepreneurial Potential: a Nine Country Study of Locus of Control and Innovativeness. Journal of Business Venturing, 16:51-75.

NIJKAMP, P. (2003). "Entrepreneurship in a Modern Network Economy.” Regional Studies, 37(4):395-405.

OECD (2006). OECD Factbook 2006: Economic, Environmental and Social Statistics. Paris: OECD.

REYNOLDS, P. (1997). "Who starts new firms? Preliminary explorations of firmsin-gestation." Small Business Economics, 9:449-462.

SCHOMBURG, H. \& TEICHLER, U. (2006). Higher Education and Graduate Employment in Europe, Springer.

SMALLBONE, D. \& WELTER, F. (2001). "The Distinctiveness of Entrepreneurship in Transition Economies." Small Business Economics, 16:249-262.

STEWART, JR. W. \& WATSON, W. \& CARLAND, J. C. \& CARLAND, J. W. (1998). "A Proclivity for Entrepreneurship: a Comparison of Entrepreneurs, Small Business Owners, and Corporate managers.” Journal of Business Venturing, 14:189-214.

STIGLITZ, J. \& DRIFFILL, J. (2000). Economics. New York: W. W. Norton.

STOREY, D. (1994). Understanding the Small Business Sector. London: Routledge.

Recebido em: 01 de abril de 2008. Primeira resposta em: 29 de abril de 2008. Aceite em: 20 de fevereiro de 2009. 